\title{
ТВОРЕЦЬ I ТВОРІННЯ, БОГ І ЛЮДИНА, СУТНІСТЬ Й ЕНЕРГІЯ В БОГОСЛОВСЬКІЙ ДУМЦІ АТАНАСІЯ ОЛЕКСАНДРІЙСЬКОГО
}

Проблема богословської інтерпретації відношення Бога і творіння - одна 3 найважливіших у богословській думці Атанасія Олександрійського ${ }^{1}$. Він радикально протиставляє Творця і сотворений світ, наголошуючи на тому, що Всесвіт, який виник із нічого, не може бути подібним до вічного та самобутнього Бога². Як зазначає Д. Брейк, саме аріанська криза спонукала Атанасія до радикального розрізнення між Творцем і творінням. Щобільше, ця теза стає “центром його богословського дискурсу”з, на відміну від орігенівського підходу єрархічності духовного та матеріально$\mathrm{ro}^{4}$. Саме протиставлення Творця і творіння ставить питання про можливість богопізання, споглядання Бога й безпосередньої участі в Його житті. Це питання загострюється ще й тим, що моральний та духовно-тілесний занепад людини після гріхопадіння формує ще одну перепону в богоспілкуванні. К. Анатоліос зазначає, що в той час, як “відношення між сотвореним і несотвореним - провідна парадигма Атанасієвої онтології, відносини між Богом та людством мають у ній найголовніше значення" 5 . Тому для Атанасія важливо не лише обгрунтувати богословську складову онтологічного зв'язку між трансцендентним та іманентним виміром Божої природи, а й показати духовно-аскетичний аспект боголюдської синергії i відновлення образу Божого в людині. Головний богословський фокус олександрійського єпископа - сотеріологічно-христологічне мислення, особливо - його Logos-sarx христологія. Прийнявши людське тіло, Слово Боже завдяки communicatio idiomatum стало відкритим для участі тих,

*Viktor Zhukovskyy, PhD, STD - Chair of Theological Department, Ukrainian Catholic University (Lviv); д-p Віктор Жуковський, доктор філософії, доктор богослов'я - Завідувач кафедри богослов’я, Український Католицький Університет (Львів)]; e-mail: viktor@ucu.edu. ua.

${ }^{1}$ Про богословську думку Атанасія Олександрійського див. Т. Weinandy, Athanasius. A Theological Introduction, Hampshire - Burlington 2007.

2 Пор. Г.В. Флоровский, Восточные Отизы IV-го века, Москва 1992, 31.

${ }^{3}$ D. Brakke, Athanasius and Asceticism, Baltimore - London 1995, 145-146.

${ }^{4}$ Пop. A. Louth, Athanasius's Understanding of the Humanity of Christ, StPatr 16 (1985) 311.

${ }^{5}$ K. Anatolios, Athanasius: The coherence of his thought, London - New York 1998, 34. 
які беруть участь у його людськості. Через сопричастя в обоженій людськості Воплоченого Божого Слова людина одержала можливість участі в божестві Бога, який перебуває в людськості Ісуса Христа ${ }^{6}$. Саме завдяки новій, боголюдській реальності невидимий та непізнаваний за природою Бог стає видимим і пізнаваним, а Божа близькість до людини остаточно звершується в особовому сопричасті й Обоженні.

Предметом розгляду цієї статті $є$ специфіка апофатичного і катафатичного методів у богословській думці Атанасія Олександрійського. Особливу увагу звернено на проблему онтологічної відстані між божественним, несотвореним і світовим, сотвореним буттям загалом та між Богом і людиною зокрема. Мета цього дослідження - представити не лише підхід великого олександрійського єпископа до розуміння безконечної буттєвої дистанції між Творцем і творінням, а й також проаналізувати способи концептуальної інтерпретації присутності трансцендентного Бога в іманентній реальності світу, які пропонує Атанасій.

Структура нашого дослідження має декілька визначальних елементів. На початку буде представлено антиномію трансцендентно-іманентної природи Божого буття в богослов'ї Атанасія, через призму його апофатичного і катафатичного методів. Далі ми розкриємо головні концептуальні моделі, якими послуговується Олександрійський єпископ, змальовуючи божественну дієву і творчу присутність у світі, а саме: Божі сходження, енергії і сили Бога. Вкінці статті особлива увага буде звернена питанню боголюдської синергії та інтерпретації Атанасієм природи і благодаті з огляду на онтологічну відмінність Творця і творіння, з одного боку, і присутність недоступного Бога у світобудові - 3 другого.

1. Апофатично-катафатичний метод. Богословське осмислення онтологічної відмінності між Творцем і світобудовою у вченні Олександрійського єпископа неможливо представити без аналізу його апофатичного та катафатичного методів, за допомогою яких він протиставляє “схованого" i "відкритого" Бога, та показує як Бог "in Se" є водночас "ad extra".

Атанасій описує трансцендентну ${ }^{8}$ іншість Бога класичною середньоплатоністичною апофатичною термінологією: “Бог - Творець світу і Цар

\footnotetext{
${ }^{6}$ Пop. Athanasius Alexandrinus, Epistula ad Epictetum 6, PG 26, 1060C.

${ }^{7}$ Пор. K. Anatolios, Athanasius, c. 37. Про трансцендентну природу Бога та богослов'я Обоження в думці Атанасія див. G. Telepneff - J. Thornton, Arian Transcendence and the Notion of Theosis in Saint Athanasios, GOTR 32 (1987) 271-277.

${ }^{8}$ Описуючи божественну трансцендентність, Атанасій використовує такі ж апофатичні терміни, як і середні платоніки. Пор. Athanasius Alexandrinus, Oratio contra gentes 22, 25-27, ed. R.W. Thomson, B: Athanasius, Contra Gentes and De Incarnatione, Oxford Early Christian Texts, Oxford 1971, 60. Яскраво виражена апофатична мова Атанасія щодо іншості Божого Буття була спрямована проти поганського ідолопоклонства. Проте Атанасієвий “платоністичний” опис трансцендентності Бога виходить поза строгий платонізм у його вченні про Боже Воплочення. Про вплив платоністичного підходу на розвиток патристичного вчення про Божу
} 
усього, який понад усіма сутностями і людським розумом"я. За своєю природою “Бог - безтілесний, безсмертний, нетлінний і ні в чому не має потреби”"10. В іншому місці Атанасій пише, що Бог "невидимий і неосяжний. [...] Ми приймаємо про Бога таку думку, що Він - всесильний, і нічого над Ним не домінує, а Він над усім панує і всім володіє" в Бозі жодного недоліку чи браку чогось ${ }^{12}$. Він “невидимий і неосяжний, перевершує все сотворене буття"13. Водночас, на думку Х. Анатоліоса, можна простежити чітку “логічну послідовність між Атанасієвим тринітарним вченням і його наголосом на невідокремленості божественної віддаленості та близькості"14. К. Анатоліос зазначає, що "внутрішнім центром узгодженості в богослов’ї Атанасія $є$ відмінність й одночасне взаємовідношення між Богом і світом"15. Змальовуючи недоступність та абсолютну віддаленість Божого Буття, єпископ використовує заперечну лексику, не обмежену лише філософським апофатизмом, а таку, що виходить за його межі й представляє катафатичну сторону Бога, описуючи Його безмірну благість і чоловіколюбність. Доброта Божа - не філософська, знеособлена, іманентна характеристика Божої природи, а особове зішестя і входження Воплоченого Бога у світ. Саме предвічний та добрий Бог любові, вмотивований любов’ю, входить в історію, щоби творити i спасти світ історії. Тут, як зазначає X. Анатоліос, можна говорити про поєднання сфери Буття і того, що повстає до буття, онтологічного виміру Бога та Його спасительної місії любові, яка вибудовує буттєвий міст над природним онтологічним розривом між сотвореним і несотвореним ${ }^{16}$.

У цій подвійній системі координат Божого Буття Атанасій наголошує на апофатичних характеристиках невидимого ( $\alpha$ ó $\alpha \tau o \varsigma)$ і неосяж-

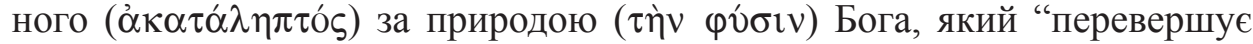
будь-яку сотворену сутність", та водночас, поєднуючи via negativa i via positiva, вказує на іншу сторону чоловіколюбивого Бога ( ó @eós): вияв Його доброти і турботи до людства, для якого Він впорядкував світ. У богомисленні Атанасія присутній акцент на природному богослов’ї. Буттєво віддалений Бог за природою також чоловіколюбний,

трансцендентність загалом та його зв'язок із вчення про таїнство Воплочення див. Anatolios, Athanasius, c. 38-47.

${ }^{9}$ Athanasius Alexandrinus, Contra gentes 2, 5-6, ed. Thomson, c. 6.

${ }^{10}$ Ibidem 22, 25-27, ed. Thomson, c. 60.

${ }^{11}$ Ibidem 29, 2-8, ed. Thomson, c. 78.

${ }^{12}$ Пop. Ibidem 39, 14, ed. Thomson, c. 106.

${ }^{13}$ Ibidem 35, 2-3, ed. Thomson, c. 94.

${ }^{14}$ Anatolios, Athanasius, c. 44.

${ }^{15}$ Ibidem, c. 3. К. Анатоліос наголошує на "подвійному" вимірі Божественного Буття: "Ми можемо простежити чітку присутність подвійності у відношеннях між Богом і творінням у вченні про Бога. Бог як предвічне буття - недоступний для творіння, і водночас Його перебування у творінні, турбота за нього походять від Його природної благості” (ibidem, c. 44).

${ }^{16}$ Пop. ibidem, c. 46-47. 
і Він провіденційно поширює й уприсутнює свою дієву любов у творінні й облаштуванні всього світу. Так непізнаваний Бог у дієвій любові об'являє себе людині і дає їй можливість пізнати себе.

“Добрий і люблячий людство Бог турбується за душі, які Він сотво-

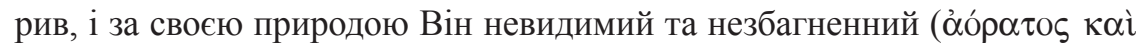

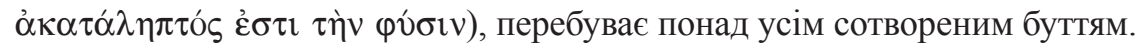
$[\ldots]$ Бог своїм власним Словом так впорядкував творіння ${ }^{17}$, що, залишаючись невидимим за природою (

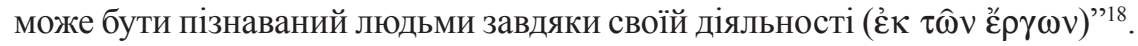

У такому ж ракурсі Атанасій осмислює природу Божих імен, які, на його думку, не стосуються трансцендентної та недоступної сутності Бога, а є “чимось навколо неї”, що виявляє Бога:

"Хтось може розуміти Бога складним, неначе акциденти і субстанція, чи оточеним й огорнутим чимось зовнішнім, неначе існує щось, що звершує Його сутність. Та коли ми кажемо «Бог» чи називаємо «Отець», ми

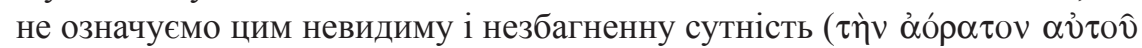

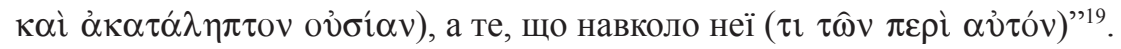

Через Богом сформований світовий порядок людина також може одержувати певне пізнання характеристик невидимого за природою Бога ${ }^{20}$.

${ }^{17}$ Світобудова в Атанасієвій космології не єдинородна цілісність, а, радше, цілісна єдність різних елементів, де індивідуальні різниці та протилежності Бог примиряє, впорядковує та гармонізує вищою силою, формуючи єдину в різноманітності світобудову. Пор. Anatolios, Athanasius, c. 47-48. Див. Athanasius Alexandrinus, Oratio contra gentes 35-38, ed. Thomson, c. 94-107. Детальніше про космологічний вимір взаємозв'язку між Творцем і творіння див. Anatolios, Athanasius, c. 47-53.

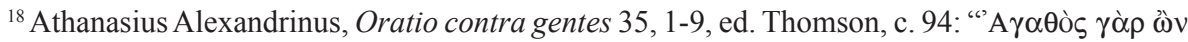

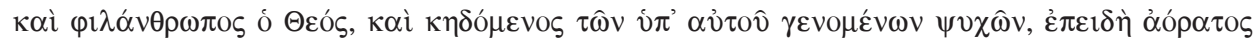

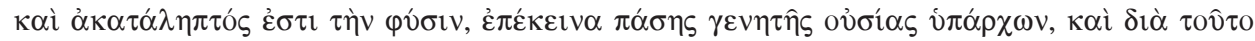

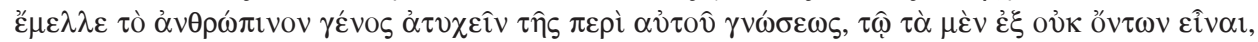

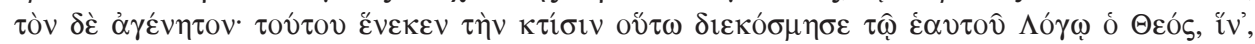

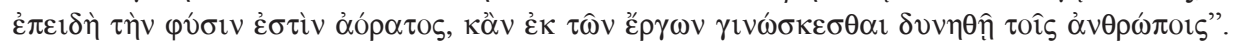

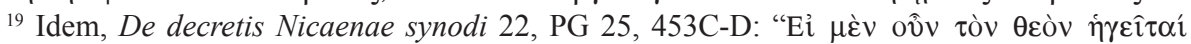

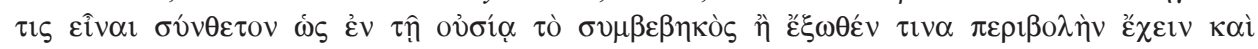

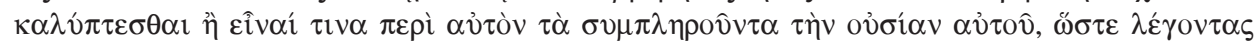

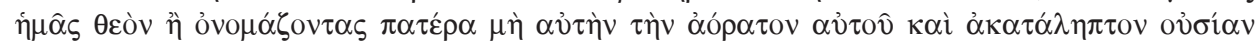

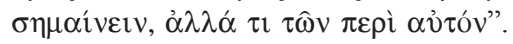

${ }^{20}$ Пор. idem, Oratio contra gentes 35, ed. Thomson, c. 94. Також див. Weinandy, Athanasius, c. 23. Атанасій наголошує на єдиному Творці єдиної гармонійної світобудови. Див. Athanasius Alexandrinus, Oratio contra gentes 39, 6, ed. Thomson, c. 106. Інший аспект - те, що множинність всіх творінь видимого світу, які перебувають у гармонії, походить від розумного творчого джерела - Бога-Отця, який, промислительно, волею і силою Божою, своєю Премудрістю і Словом, Господом Ісусом Христом, встановлює гармонійний порядок, керує і розпоряджається всім у світі, пор. ibidem 40, ed. Thomson, с. 110-112. Олександрійський єпископ чітко розмежовує християнське і філософське розуміння Слова Божого: “Словом називаю не те, що 
Отож, з одного боку, Атанасій підтверджує непізнаваність Божого Буття, коли наголошує на тому, що “зрозумілий Бог - не є Богом"21. 3 другого в богословській думці Атанасія знаходимо чітке розрізнення між непізнаваною сутністю самобутнього та нічим неохопного Бога і Його “тугою” чи “жагою” бути "назовні" через свої дієві та впорядковувальні сили, які виявляють божественну щедрість. Саме 3 причини Божої благості та Його бажання виявити свою чоловіколюбність, які перевершують будьяке людське поняття доброти, Слово Боже воплотилось і стало людиною.

“Бог існує сам у собі, охоплюючи всі речі і залишаючись нічим неохопленим; всередині всього, згідно з Його власною добротою і силою

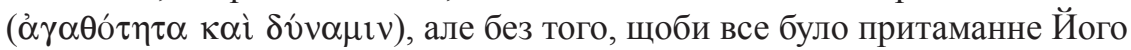

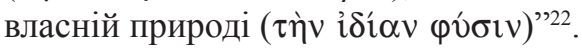

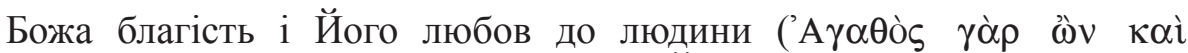

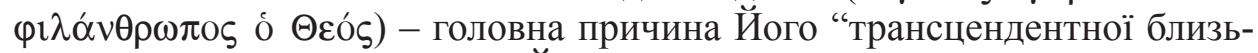
кості” до всього сотвореного. Його “активний” філантропний “вихід до” грунтований на цій основоположній характеристиці божественної природи. Бог творить і проникає у всі види сотвореного світу для того, щоби виявити свою любов до нього ${ }^{23}$. Спостерігаємо своєрідну гармонію між етичним й онтологічним вимірами в характеристиці Божого Буття, яка,

втілене і вроджене в кожній сотвореній речі, і яке дехто звик називати насінним, яке не живе, ні про що не думає, нічого не уявляє, а діє лише зовнішнім мистецтвом, відповідно до знання того, хто його вкладає. [...] Розумію живого і дієвого Бога, джерельне слово Благого до всіх, Бога-Слово, яке відрізняється і від сотворених речей, і від усілякого творіння, і є, власне, тим єдиним Словом благого Отця, яке облаштувало Всесвіт й осяює його своїм промислом. Як добре Слово доброго Отця, Воно добре облаштувало порядок Всесвіту, поєднюючи протилежне 3 протилежним і влаштовуючи з цього єдину згоду" (ibidem 40, 23-35, ed. Thomson, c. 110-

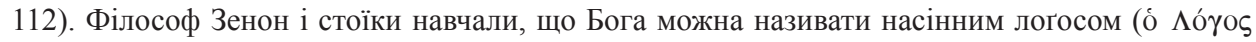
$\sigma \pi \varepsilon \rho \mu \alpha \tau \iota \kappa o ́ s)$. Основу всіх сотворених речей, яку вклав у них Бог, називають насінними лого-

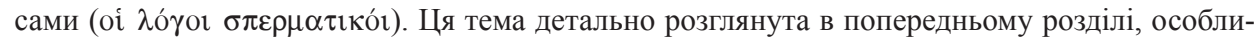
во в підрозділі, присвяченому богословській думці Юстина Мученика. Водночас Атанасій наголошує, що "всемогутнє, вседосконале, святе Отче Слово, зійшовши у Всесвіт, скрізь поширило свої сили, осяявши видиме і невидиме, все в собі вміщає та скріплює, не залишивши нічого без своєї сили, все у всьому оживляє і зберігає, окремо кожну річ і все у сокупності" (ibidem 42, 1-6, ed. Thomson, c. 114). Атанасій різко відкидає стоїчне уявлення про насінні сло-

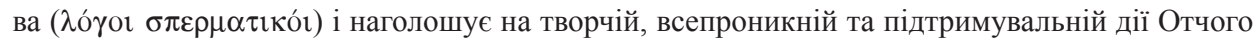
Слова. Особлива риса Атанасієвого мислення - акцент на подвійності творіння, в якій він розрізняє і протиставляє мінливу сутність творіння і печать Слова-Премудрості, яка оберігає творіння у бутті. Пор. Флоровский, Восточные Отиь IV-го века, с. 32.

${ }^{21}$ Athanasius Alexandrinus, Sermo ad Antiochum ducem 1, PG 28, 597D. Цей текст приписують Псевдо Атанасію Олександрійському. Див. K. Ware, God Hidden and Revealed: The Apophatic Way and the Essence-Energies Distinction, "Eastern Church Review" 7 (1975) 126.

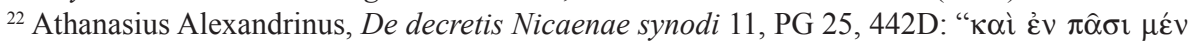

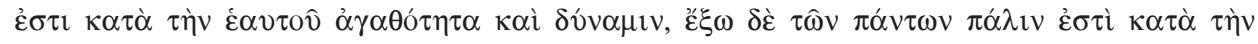

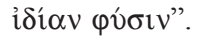

${ }^{23}$ Пop. idem, Oratio contra gentes 41, ed. Thomson, c. 112-114. 
очевидно, бере витоки ще задовго до приходу Христа - у платонівських і неоплатоністичних підходах ${ }^{24}$.

К. Анатоліос наголошує на дуже важливій деталі в богослов'ї Атанасія, кажучи, що одна 3 головних його максим - це те, що дії повинні стосуватись природи ${ }^{25}$. Атанасій пише:

“Якщо дії гідні богів, тоді ті, що їх звершують, повинні бути богами. Але якщо ж вони є діями людей, i їх дискредитують, [...] якщо вони діють так, що це виявляє їхню людськість, то це не властиве богам. Вчинки повинні відповідати їхній природі так, щоб діяча можна було пізнати за

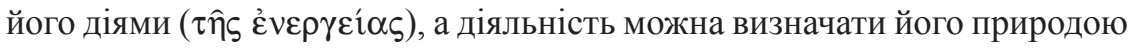

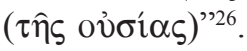

За допомогою діалектики зв'язку між Божою природою і Його діяльністю Атанасій красномовно представляє дві божественні реальності: Божу трансцендентність і Його близькість до іманентного світу. Божественна творча ініціатива і Божі діла як ії результат перевершують радикальні онтологічні відмінності й об'являють “енергійного” Бога, для якого не існує непрохідного онтологічного розділення ${ }^{27}$. Атанасій,

${ }^{24}$ Тема взаємин між Богом і творінням - один із фундаментальних елементів контроверсії між Атанасієм та Арієм, який мав протилежну до олександрійського єпископа позицію. Для нього особа і діяльність Христа має, головно, космологічні межі. Такий підхід відзначається чітким неоплатоністичним забарвленням. Тут Христос - створений і виконує роль посередника між творінням та трансцендентним Богом, який залишається непізнаваним і схованим у собі. Про це детальніше див. А. Harnack, Lehrbuch der Dogmengeschichte, vol. 2, Freiburg Leipzig 1894, 217. Це ж зауважує Р. Вільямс, який зазначає, що Христос Арія “свідчить про непрохідну прірву між Богом і всім іншим" (R. Williams, Arius: Heresy and Traditio, London - Darton 1987, 177).

${ }^{25}$ Пop. Anatolios, Athanasius, c. 40.

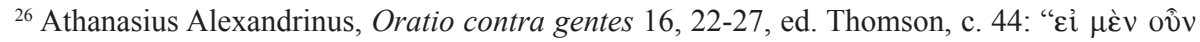

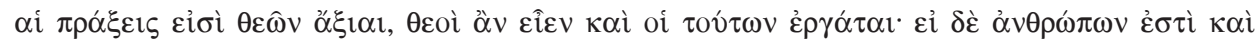

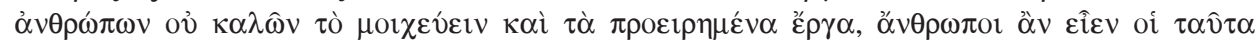

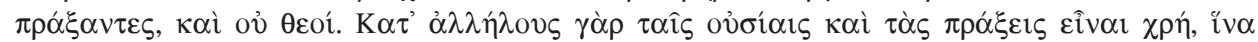

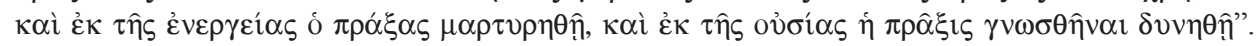

${ }^{27}$ Одним з Атанасієвих текстів, у якому він розкриває своє розуміння Божої неосяжності і промислительної турботи за все творіння, є 35 глава Oratio contra gentes, де він, посилаючись на Послання апостола Павла до римлян (Рим. 1, 20) і Діяння апостолів (Дія. 14, 15-17), пояснює, як неосяжний i “невидимий за природою” Бог, у своїй чоловіколюбності через результати своєї творчої діяльності виявляє себе як видимий і збагненний Творець, організатор і керівник усього, що існує: “Бог благий, чоловіколюбний, доброчинний щодо сотворених Ним душ. Оскільки ж за природою Він невидимий і неосяжний, понад будь-яку сотворену сутність, а людський рід, який походить із нічого, не досяг би знання про Нього, несотворенного, тому Він своїм Словом так облаштував творіння, щоб Його, невидимого за природою, могли пізнавати люди хоча б із Його діл. [...] Із впорядкованості світу можна пізнати його Творця і Сотворителя-Бога, хоч і невидимий Він тілесним очам. [...] Він так впорядкував творіння, що, залишаючись невидимим за природою, Він упізнаваний за своїми ділами” (Athanasius Alexandrinus, Oratio contra gentes 35, 1-3, 5-9, 16-18, ed. Thomson, c. 94-96). Подібно Атанасій 
змальовуючи Бога як Господа сил, які походять від Нього як всемогутнього Правителя, котрий всім управляє, водночас чітко зазначає, що це не Божественний Логос, не Син Божий, який, хоч і керує творінням, проте абсолютно відрізняється від усього сотвореного. Мовиться про Господні сили, які походять від Бога-Отця, відрізняються від самого Божественного Логосу, головують над усім й організовують все в іманентному світі ${ }^{28}$.

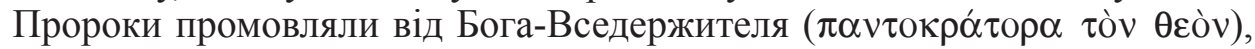
Управителя всього, що Ним сотворено, через Сина-Слово, якому і дано владу над усім. Син не виступає окремою Божою силою, а радше посередником сил, які походять від Отця через Сина і наповнюють буттям Всесвіт. Атанасій наголошує, що пророки “називають Бога Господом сил ( $\tau \varepsilon$ кúpıov $\tau \hat{\omega} v \delta$ vvó $\mu \varepsilon \omega v)$ і кажуть це не так, ніби Слово - це одна 3 цих

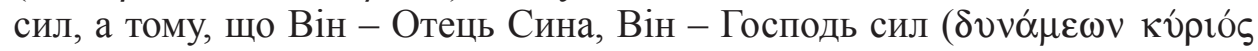

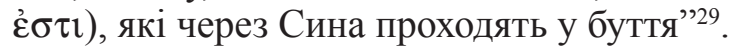

говорить про взаємозв'язок між абсолютно іншою Божою природою і Його видимими ділами у світі в 32 главі Oratio de incarnatione Verbi. “Богові притаманно бути невидимим, але пізнаємо Його з діл. [...] Тому, якщо немає діл, то справедливо, що не вірять невидимому” (idem, Oratio de incarnatione Verbi 32, 2-6, ed. R.W. Thomson, B: Athanasius, Contra Gentes and Oratio de incarnatione Verbi, c. 210-212).

${ }^{28}$ Остаточне об'явлення правди про онтологічну близькість Бога до творіння і людини звершилось, зокрема, в таїнстві Воплочення Божого Логосу. У цій “точці” поєднання трансцендентного й іманентного, невидимий, непізнаваний і недоступний за внутрішньою природою Бог стає видимим, пізнаваним, доступним для людини. Божа слава та честь виявляються в Його турботі за творіння, яка досягає своєї вершини саме в Боговоплоченні. Буттєве особове входження Логосу у світ перевершило онтологічне розділення між абсолютом іншості, яка пролягла прірвою між божественною та сотвореною реальностями, і відкрило можливість Обоження людини та світу. Таку сотеріологічно-онтологічну лінію богословлення Атанасій успадкував від Іринея Ліонського. К. Анатоліос, представляючи концепцію зв'язку між Божою ікономією і світом та між Божественним Логосом і Отцем у богословській думці олександрійського єпископа, наголошує на невіддільній співдії Слова й Отця. "Проте ця невіддільна співдія не представлена тут у первинних метафізичних термінах як артикуляція внутрібожественної реальності, а радше з перспективи ікономічної Трійці. Головний пункт цього представлення - взаємини між людством і Богом, всеохопний контекст відносин між творінням загалом і Богом. [...] Атанасієва думка тут полягає саме у вираженні цих стосунків як одного цілого між творінням і людством, з одного боку, і Богом як Словом Отця, яке комунікує та об'являє Отця, - $з$ іншого" (Anatolios, Athanasius, c. 44-45). Детальніше про це див. Athanasius Alexandrinus, Oratio contra gentes 34, ed. Thomson, c. 92-94; 40, ed. Thomson, c. 108-112; 46, ed. Thomson, c. 126-130; 47, ed. Thomson, c. 130-132; idem, Oratio de incarnatione Verbi 1, ed. Thomson, c. 134-136; 3, ed. Thomson, c. 138-142; 7-8, ed. Thomson, c. 148-152; 11, ed. Thomson, c. 158-160; 14-15, ed. Thomson, c. 166-172.

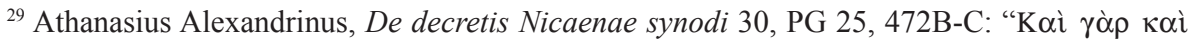

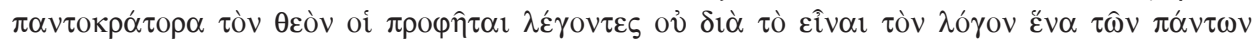

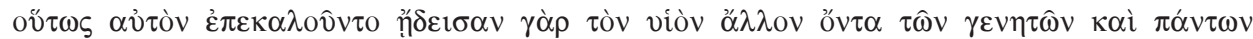

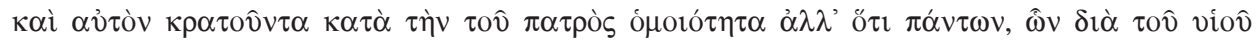

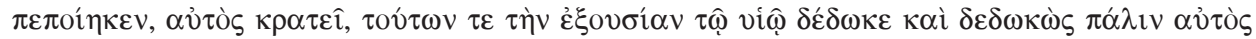

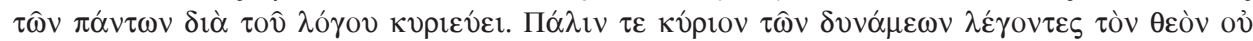


2. Божі сходження ad extra. Божественна творча, життєдайна і керуюча всюдисущність окреслюється Олександрійським єпископом як Божі

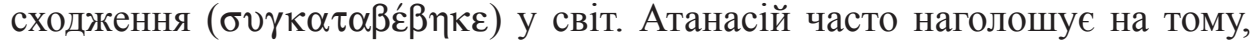
що Слово зійшло у світ для того, щоб підтримувати в бутті все сотворене та скеровувати його до участі в Отцізі. Х. Анатоліос зазначає, що “подібність між творінням і Богом є відображенням божественного сходження ad extra, в той час, як божественна трансцендентність маніфестована в акті приведення творіння з нічого до буття, у підтримці його в бутті. Так подвійний аспект взаємин між Богом та світом відображений у творінні завдяки дуальності між властивою йому буттєвою слабкістю і дарованій участі в божественному житті" 31 .

Наголос Атанасія на абсолютній іншості Божого Буття сильно пов'язаний з рівноцінним акцентом на божественному сходженні в сотворену реальність. Такий підхід показує своєрідний баланс і водночас повноту звершення Божого задуму щодо світобудови. "Божественне сходження виявляється всередині внутрішньої структури космосу та людства і виконує роль конститутивного чинника цих структур"32. Х. Анатоліос зазначає: “Основоположна структура стосунків між Богом і творінням від початку визначена божественним сходженням у формі всеохопної присутності «в», і провидінням «над» усім творінням, що походить без-

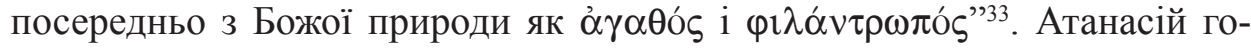
ворить про сходження у світ Слова Божого, який виявляє Отця та дає творінню можливість Його пізнавати.

"Хто міг би дати мірку Отцеві, щоб дослідити силу Його Слова? Він є Слово та мудрість Отця і водночас сходження ( до творіння, щоб дати йому ідею та знання Його Родителя"з4.

Звертаючи увагу на поняття сходження, Атанасій не вносить онтологічного розрізнення у внутрітроїчне буття Бога і цим монархічно не вивищує Бога-Отця відносно Сина ${ }^{35}$. Сходження Слова до творіння - це маніфестація Бога-Отця, який у Воплочені Сина Божого, неначе міст, перекриває непрохідну дистанцію між Творцем і творінням. Динамічна активність Слова Божого, який єдиносущний з Отцем, є буттєвим єднанням вічності з часом - це сходження Божої особової Отцівської любові

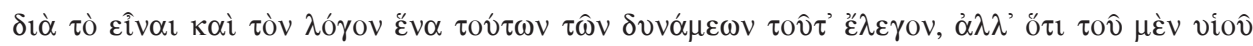

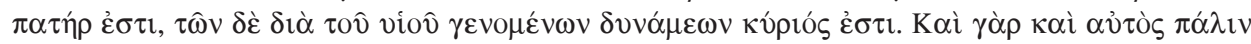

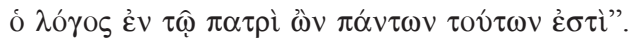

${ }^{30}$ Пop. idem, Oratio contra gentes 41, ed. Thomson, c. 112-114.

${ }^{31}$ Anatolios, Athanasius, c. 53.

${ }^{32}$ Ibidem, c. 208.

${ }^{33}$ Ibidem, c. 40.

${ }^{34}$ Athanasius Alexandrinus, Oratio contra gentes 47, 1-4, ed. Thomson, c. 130.

${ }^{35}$ Пop. Anatolios, Athanasius, c. 46. 


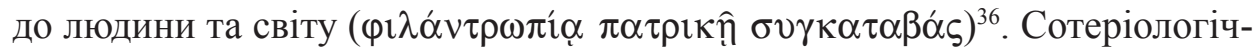
ний вимір богопізнання - це головний мотив Божого сходження. Все, що Отець робить у своєму Слові, відображає його “життя заради” людини і світу, щоби все сотворене могло впізнати і взяти участь у своєму чоловіколюбному Родителі.

“Для всіх очевидно, що не заради самого себе як творіння і не тому, що в сутності має якусь спорідненість зі всім сотвореним. Слово названо «Первородним» творіння радше тому, що Слово на початку формування

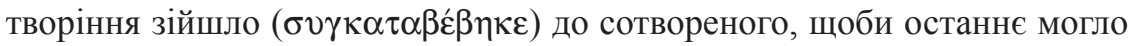
прийти в буття. В іншому випадку сотворене не могло б перенести невимірної природи і сяйва Отця, якщо б завдяки Отцівському чоловіколюбію Слово не зійшло до них на допомогу і, взявши владу над ними, привело до існування. Окрім того, ще 3 тієї причини, що через сходження Слова Ним усиновлюється саме творіння. [...] Слово стає «Первородним» творіння як щодо тих, кого творить, так і введенням у сам Всесвіт"з7.

3. Енергійний вимір сходження Божого Слова у світ. Бог-Трійця, Своєю волею, у Своєму Слові, дієво сходить і проникає у всі виміри творіння через енергію, промисел і силу. Вчення Атанасія про трансцендентного й іманентного Бога близько пов'язане з його тріадологічною доктриною. Простежується чітка єдність між вченням про Трійцю і наголосом на невіддільності божественної іншості й близькості щодо сотвореного світу. У різний спосіб даруючи благодать, Бог залишається єдиним як у своєму внутрішньому бутті (ad intra), так і у діяльності назовні (ad extra). Водночас поряд з єдністю Бог різниться як іпостасно, так і в діяльності назовні ${ }^{38}$. Маємо тріадологічну антиномію єдності-розрізнення як у внутрітроїчному бутті Бога, так і в Його ікономічній діяльності ${ }^{39}$. Георгій Флоровський зазначає, що для Атанасія "існує таїнственне онтологічно реальне розрізнення між сутністю (ousia) чи природою (physis) Бога, спільною для трьох Осіб Пресвятої Трійці, і Божою Троїчною волею $a d$ extra, через яку Бог має відносини зі своїм творінням"40.

${ }^{36}$ Пop. ibidem, c. 113.

${ }^{37}$ Athanasius Alexandrinus, Orationes contra Arianos II 64, PG 26, 284A-B.

${ }^{38}$ Пор. X. Morales, La théologie trinitaire d'Athanase d'Alexandrie, Collection des Études Augustiniennes, Série Antiquité 180, Paris 2006, 170-187.

39 Детальніше про тріадологічний вимір божественної діяльності в Атанасія див. ibidem, c. $155-200$.

${ }^{40}$ G. Florovsky, The Concept of Creation in St. Athanasius, StPatr 6 (1962) 36-57. Г. Флоровський, говорячи про інтерпретацію ранніми Отцями буття й об'явлення Пресвятої Трійці, зазначає: “Саме таїнство Пресвятої Трійці часто інтерпретували у двозначному космологічному контексті - переважно, не як суто таїнство Божого Буття, а радше в перспективі творчої і відкупительної Божої діяльності та Його само-відкриття у світі. У ранньоцерковній патристиці це питання було головною проблемою в інтерпретації богослов'я Логосу як апологетами загалом, так і в Іполита й Тертуліана зокрема. Всі ці письменники не могли послідовно 
Для того, щоб говорити про конвергенцію Божої трансцендентності й іманентності, важливо йти шляхом діалектичного осмислення зв'язку між Божою природою і Божими “ділами”. У цій діалектиці концепція особи та динамічної присутності у світі Воплоченого Слова відіграє провідну роль ${ }^{41}$. Обговорюючи тему Воплочення, олександрієць означує природу Божественного Логосу як "відмінного у своєму бутті від Всесвіту і водночас присутнього у всіх речах завдяки власній силі, яка надає всьому порядок"42. Г. Флоровський зазначає, що у христологічно-космологічній

розрізнити між категоріями Божого «Буття» і тим, чим є Божественне «Об'явлення» ad extra у світі" (ibidem, с. 38). Г. Флоровський зауважує в богословській думці Атанасія чітке розрізнення між “сутністю” та “силами”, але концепція александрійського богослова має цілком іншу, нову конотацію, ніж у філософських підходах Філона, Плотіна, християнських апологетів чи у свого попередника Климента Олександрійського. Це розрізнення “ніколи не стосувалося взаємин між Богом і Логосом, як це робив навіть Оріген. Тепер вона служила новій меті: строгому розрізненню між внутрішнім буттям Бога і Його творчими та «промислительними» виявами ad extra в сотвореному світі. Світ перебуває понад прірвою свого власного небуття і безсилля, завдячуючи своєму справжньому існуванню керівній Божій волі й доброті зокрема, Його стимулюючій «благодаті» як sola gratia. Благодать залишається у світі” (ibidem, c. 47). Г. Флоровський також наголошує на тому, що “Боже Буття” має абсолютний онтологічний пріоритет над Божою волею і дією. Пор. ibidem, c. 48. "Існування світу, навпаки, «зовнішнє» до Божественної сутності та вкорінене лише в Божественній волі. [...] Бог не «вибирає» своє Буття. Він просто є. [...] Справді, «творити», тобто виявляти себе ad extra, притаманно для Бога. Але цей вияв $є$ дією Його волі і в жодний спосіб не $є$ поширенням Його власного Буття" (ibidem, c. 49). Г. Флоровський до цього додає, що “творіння [...] назовні від Бога [...] не може «спів-існувати» з Богом. Але це питоме обмеження їхньої природи в жодному сенсі не применшує сили Творця. Головна думка Атанасія щодо цієї проблеми $[\ldots]$ - тотожність природи щодо походжень і різниця природ у творінні” (ibidem, c. 51-52). Також див. Athanasius Alexandrinus, Orationes contra Arianos I 26, PG 26, 66. Про значення понять "природа" i “благодать” у богословській думці Атанасія див. G.D. Dragas, The Relation of Nature to Grace in the Writings of St. Athanasius, в: Saint Athanasius of Alexandria. Original Research and New Perspectives, Rollinsford 2005, 1-78.

${ }^{41}$ Пop. Anatolios, Athanasius, c. 35.

${ }^{42}$ К. Анатоліос, визначаючи богословський підхід Атанасія щодо дієвої Божої присутності у світі, наголошує на гармонізуючій ролі божественної діяльності у сотвореному світі: “Атанасій особливо вражає своїм спостереженням того, що феноменальний Всесвіт не є простою однорідністю, а радше загальною єдністю й узгодженістю, встановленою множинністю елементів. Особливо ця єдність у розрізненні свідчить про вищу силу, яка примирює відмінності та гармонізує опозиційні тенденції індивідуальних елементів у зв'язне і зрозуміле ціле. [...] Підхід стоїків був корисний для Атанасія, як і для інших ранньохристиянських письменників, оскільки вони забезпечували термінологією і концептуальними засобами, щоб поняттєво артикулювати Божий промисел, всюдисущність і глибинне проникнення у світ - у слові й іманентності. [...] Атанасій запозичує стоїчну термінологію, щоб означити роль Слова як гаранта гармонії і порядку у Всесвіті. Він обережно робить розрізнення між Словом Отця

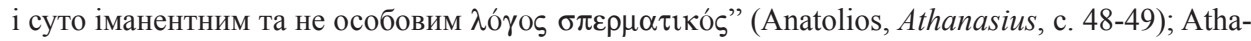

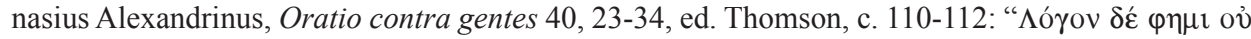

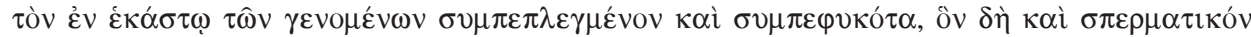

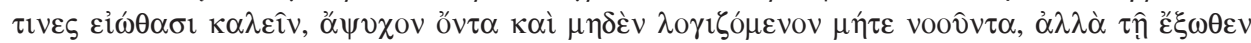


думці Атанасія “присутня цілковита неподібність між Логосом і творінням. Логос присутній у світі, але лише “динамічно”, тобто своїми “силами”. Натомість у своїй власній “сутності” Він перебуває поза світом"43.

У полеміці з Арієм і його послідовниками Атанасій розвиває вчення про Боже Слово й тісно пов'язує Його творчу дію у Всесвіті зі спасительним Воплоченням. Г. Флоровський зазначає, що олександрійський єпископ об'єднав ці два таїнства - творіння і Воплочення - поняттям “вхід Слова у Всесвіт"44. У 17 главі твору “Про Воплочення" Атанасій розгортає свою концепцію божественної діяльності у світі творіння, відмінного від Божого світу. Розглядаючи божественність і людськість Воплоченого Слова Божого, Атанасій характеризує Його творчі взаємини з творінням. Він наголошує як на своєрідному енергійному промислительному проникненню Слова у світ, так і на Його трансцендентній самобутності. Його підхід гармонійно поєднує христологічний, “енергійно-силовий” та космологічний виміри дії Воплоченого Слова у світі.

“Слово не було ув'язнене у своєму тілі та Його присутність у ньому не була перепоною для того, щоб з'являтися в іншому місці. Коли Воно мешкало у своєму тілі, то не припиняло керувати Всесвітом через свою

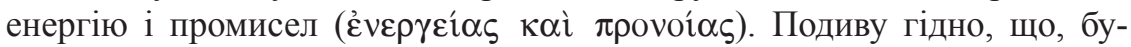
дучи Словом, Його ніщо не утримує, а радше Воно само все утримує.

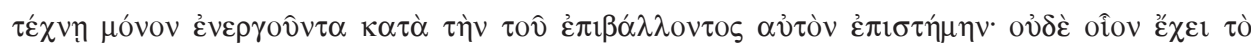

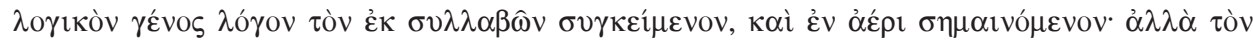

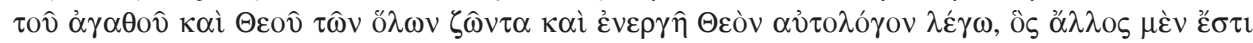

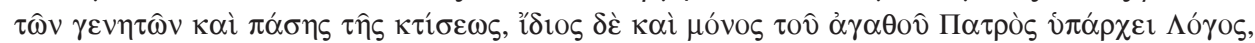

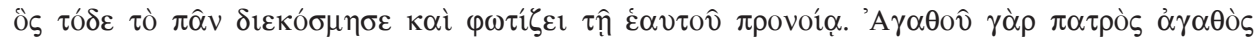

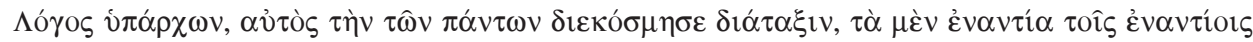

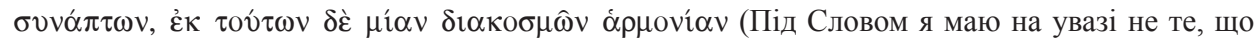

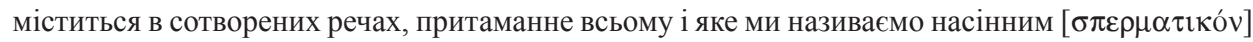
принципом, без душі та сили розуму чи думки, а лише працює в зовнішній спосіб, відповідно застосовуючи своє вміння. Мовиться не про таке слово, яке належить розумним істотам і містить у собі склади, послуговується повітрям як засобом висловлення. Маю на увазі живе й могутнє Слово доброго Бога Всесвіту, справжнє Слово, яким є Бог, яке відрізняється від сотворених речей і всього творіння, Сдине власне Слово благого Отця, який своїм промислом впорядкував і просвітив цей Всесвіт. Будучи добрим Словом доброго Отця, Воно облаштовує всі речі і поєднує протилежності, зводячи їх до єдиного гармонійного порядку". Космологію Атанасій подає в своїй “космологічній частині” праці Oratio contra gentes, див. ibidem 35-40, ed. Thomson, c. 94-112.

${ }^{43}$ Florovsky, The Concept of Creation in St. Athanasius, c. 46-47. Розглядаючи питання трансцендентності Божого Слова щодо творіння і Його дієвої присутності у світі, К. Анатоліос зазначає, що, “найглибше проникаючи у світ, Бог не перестає бути цілком інакшим, а Слово - бути іншим, аніж творіння. I навпаки, божественна іншість не спричиняє віддаленості від творіння, так само, як Слово могутньо і глибоко присутнє у творінні i, водночас, сутнісно належить до трансцендентності Отця" (Anatolios, Athanasius, с. 45). Див. Athanasius Alexandrinus, Oratio contra gentes 47, ed. Thomson, c. 130-132.

${ }^{44}$ Флоровский, Восточные Отиьы IV-го Века, с. 32. 


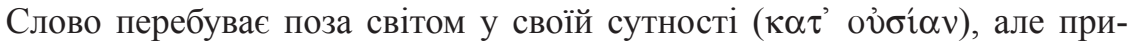

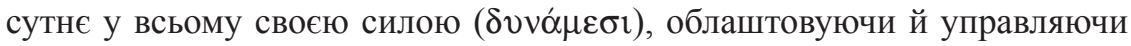
усім і поширюючи свій промисел над усім. Воно понад усім й об'являє у всьому свій промисел, дає кожній речі життя, все утримує, все вміщає, але, залишаючись нічим не обмеженим, перебуває винятково й цілковито у своєму Отці. Слово само животворить людське тіло, перебуваючи як у всьому загалом, так і в кожній його частині зокрема. Воно - Джерело життя для всього Всесвіту, в кожній його частині, для всіх істот. Проте все одно перебуває поза ним, відкриваючись у світі ділами як через своє

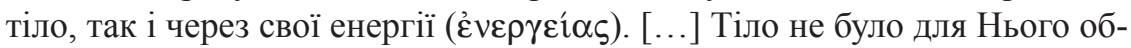
меженням, а інструментом для того, щоби Воно могло бути і в ньому, і у всьому, і поза всім, перебуваючи лише в Отці. Водночас вражає, що як людина Воно жило людським життям і як Слово утримувало життя Всесвіту, і як Син було в постійному зв'язку з Отцем. [...] Його перебування у всьому не означає, що Воно розділяє природу всього, але лише те, що Воно усьому дає властиве існування і все в ньому утримує. Як сонце не оскверняється від того, що проміння контактує із земними об'єктами, а радше просвічує й очищає їх, так і Той, хто сотворив сонце, ніколи не оскверняється, являючись у тілі, а радше тіло очищається та оживляється від Його перебування в ньому"

Х. Анатоліос, коментуючи цей текст, зазначає, що “сутнісно-силове розрізнення в мисленні Атанасія виявляє розрізнення між божественною сферою in se, яка охоплює Отця і Сина (не згадує Духа), й ad extra"46. В іншому місці він наголошує, що “для Атанасія, божественна самобутня велич і слава чітко виражена в тому факті, що буття всього творіння походить з участі в божественній силі, а відтак, відношення до Бога - властивий і конститутивний чинник структури сотвореної реальності"47. Божа діяльність анулює відокремлення сотвореної і несотвореної природ, яке унеможливлювало спілкування та богопізнання ${ }^{48}$. Важливим у думці

${ }^{45}$ Athanasius Alexandrinus, Oratio de incarnatione Verbi 17, 1-13, ed. Thomson, c. 174-176:

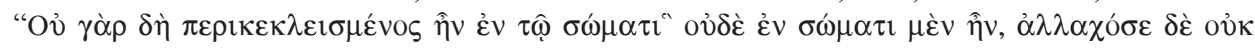

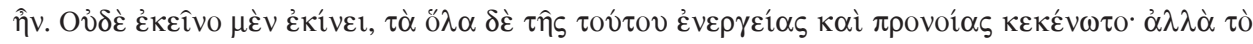

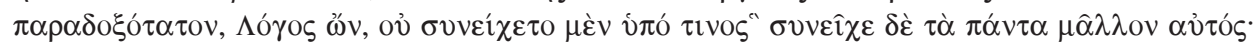

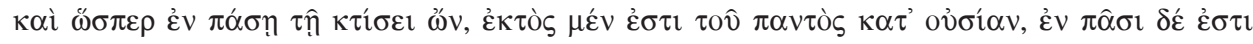

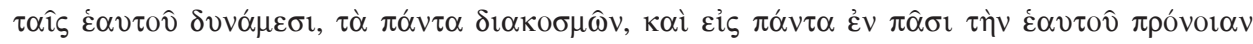

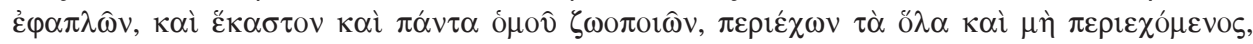

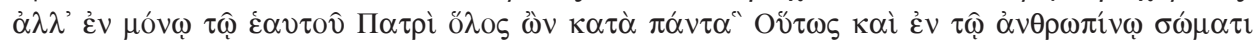

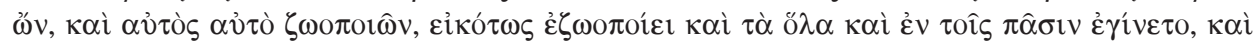

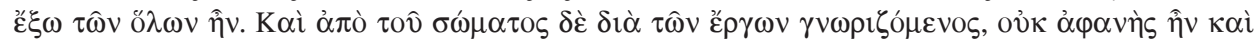

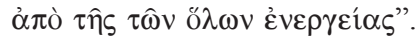

${ }^{46}$ Пор. Anatolios, Athanasius, c. 46. Про вплив Атанасія на Григорія Паламу див. Florovsky, The Concept of Creation in St. Athanasius, c. 36-52.

${ }^{47}$ Anatolios, Athanasius, c. 208.

${ }^{48}$ Пop. ibidem, c. 38. 
Атанасія $є$ акцент на природному вимірі як Божої віддаленості, так і Його філантропічної близькості до сотвореного світу. Саме всюдиприсутність Божої турботи та підтримки всього творіння демонструє Його любов до світу. Саме притаманний Божій природі вияв Його дієвої доброти і любові вибудовує міст між онтологічно різними “берегами” сотвореного й несотвореного. Як ця різниця, так і буттєве подолання цієї дистанції мають свою основу у природі Бога 49 . У такій боголюдській динаміці “наведення мосту” над прірвою між сотвореним і несотвореним буттям осмислює Атанасій природу Божого буття, Його творіння та Його Воплочення ${ }^{50}$. Слово безпосередньо занурюється в сотворений світ повнотою своєї божественної природи, водночас залишаючись у цій же природі абсолютно іншим від нього. Хоч Слово і діє як посередник, проте в Атанасієвій думці немає субордиціоналізму, притаманного для ранньо-християнської тріадології. Близькість Бога до світу “через” і “в” Його Слові, як зауважує Х. Анатоліос, "не пом'якшує” Його трансцендентності. Бог-Слово не перестає бути абсолютно іншим за природою, ніж світ сотвореного. Воно сутнісно належне до трансцендентності Отця, не дивлячись на те, що своєю силою близько проникає і наповнює всю реальність Всесвіту ${ }^{51}$. Завдяки Воплоченню Божого Слова радикальна протилежність Божого та сотвореного буття не заперечує як участі Бога у всьому сотвореному, так і причастя всього світу до Слова Божого, який своєю силою й енергією життєдайно та творчо все в ньому звершує, вибудовуючи струнку, збалансовану і гармонійну світобудову ${ }^{52}$.

“Боже Слово, осяюючи й оживотворяючи все своїм помахом, приводить у рух і благоустрій, творячи єдиний світ, і не залишає поза своїм порядком невидимі сили, які Творець цілковито охоплює, утримує та животворить порухом свого промислу".

I далі, повторюючи сказане, уточнює:

“Боже Слово одним простим порухом волі, своєю силою, приводить у рух й утримує цей видимий світ і невидимі сили, вкладаючи в кожну властиву їй діяльність. Отож, Бог приводить у рух божественні сили, а видимі речі - так, як ми це бачимо"53.

Бог об'являє себе у Слові, яке поширюється і наповнює всі виміри буття, залишаючи в цілісності та кожній окремішності печать і подобу своєї Премудрості ${ }^{54}$. А. Петерсен зауважує, що для Атанасія світ має

\footnotetext{
${ }^{49}$ Пop. ibidem, c. 41.

${ }^{50}$ Пop. ibidem, c. 41-44.

${ }^{51}$ Пор. ibidem, c. 45.

52 Пор. Флоровский, Восточныле Отизы IV-го века, с. 31.

${ }^{53}$ Athanasius Alexandrinus, Oratio contra gentes 44, 16-19. 25-29, ed. Thomson, c. 120-122.

${ }^{54}$ Пор. Флоровский, Восточныле Отизы $I V$-го века, с. 31.
} 
своєрідне сакраментальне значення. Його існування та гармонійна світобудова виявляють Боже буття ${ }^{55}$. Ця сакраментальність може також стосуватись людського тіла, оскільки впорядкованість світу й Божу діяльність людина сприймає саме через тілесні відчуття ${ }^{56}$. Бог-Отець встановив безпосередні, непорушні, унікальні та багатогранні стосунки єдності між своїм Словом та творінням і як його Творець, і як Управитель всього сотвореного $^{57}$. Отець через Сина надає сутнісне буття всьому творінню, влаштовує, оберігає й турбується про нього своїм промислом, унеможливлюючи його повернення в небуття ${ }^{58} .3$ одного боку, це божественний Логос як трансцендентне, відмінне від творіння Буття, все влаштовує, з іншого - Він перебуває у творінні й має безпосередній стосунок із ним. Саме в цьому полягає центральний таїнственний вимір творіння: трансцендентний Бог-Творець своїм Словом все приводить до буття, глибинно проникає в нього, незбагненно поєднується з ним і водночас залишається безконечно відділеним від нього.

Т. Вейнанди виокремлює чотири Атанасієві порівняння, які той застосовує для ілюстрації відношення Божого Слова до світобудови ${ }^{59}$. Поперше, Боже Слово як Божа Мудрість, перебуваючи в Отці, подібне до музиканта, який, настроївши ліру-Всесвіт, неперевершено виконує одну єдину й гармонійну мелодію творіння та упорядкування світу ${ }^{60}$. По-друге, Атанасій порівнює Слово до керівника хору. По-третє, Слово як душа' ${ }^{61}$,

${ }^{55}$ Пop. A. Pettersen, Athanasius, London 1995, 46.

${ }^{56}$ Пop. idem, Athanasius and the Human Body, Bristol 1990, 4.

${ }^{57}$ Пор. Athanasius Alexandrinus, Oratio contra gentes 41, ed. Thomson, c. 112-114. Також див. A. Pettersen, A Good Being Would Envy None Life: Athanasius on the Goodness of God, "Theology Today" 55 (1998) 59-68.

${ }^{58}$ Пор. Athanasius Alexandrinus, Oratio contra gentes 41, 3, ed. Thomson, с. 114. Щодо інтерпретації творчої діяльності Отця через Сина Й. Куастен зазначає, що Атанасій не розділяє думки, за якою Бог-Отець потребував Логоса як своєрідного посередника для справи творіння світу, як про це говорив Арій, наслідуючи думку Філона й Орігена. Олександрієць відкидає Арієву думку, згідно з якою Бог, бажаючи створити світ, спочатку створив Сина і Слово, неначе руку, за посередництвом якої Він творить світ. Див. Quasten I 67.

${ }^{59}$ Пор. Weinandy, Athanasius, с. 22, п. 21.

${ }^{60}$ Пор. Athanasius Alexandrinus, Oratio contra gentes 42, 3-4, ed. Thomson, c. 114.

61 Т. Вейнанди у впровадженні в богословську думку Атанасія критикує думку Дж.Н.Д. Келлі, який зазначав, що Слово діє у світі, як душа в тілі. Це нагадує стоїчну модель, де слово відіграє роль душі творіння. Див. J.N.D. Kelly, Early Christian Doctrine, London 1968, 285. Пор. Athanasius Alexandrinus, Oratio contra gentes 43, ed. Thomson, c. 118-120. Т. Вейнанди зазначає, що попри те, що Слово впорядковує все творіння, Його дія не розглядається як притаманний сотвореному світу конститутивний принцип, а радше як результат діяльності трансцендентного божественного Творця. Див. Weinandy, Athanasius, с. 22, п. 22. Із цієї думки Т. Вайнанди не зрозуміло, чому саме дію трансцендентного Бога через своє Слово не можна інтерпретувати як закладені Творцем буттєві принципи у всі іманентні форми світової реальності. Те, що Слово пов'язане зі своїм творінням, як душа з тілом, вказує на те, що Слово 
що рухає нашими почуттями. Й останнє, Атанасій уподібнює Слово до правителя, який будує місто й управляє ним ${ }^{62}$.

Отож, участь Воплоченого Слова як особового божественного агента в сотвореному світі, що відкриває буттєву можливість участі творіння в Божій діяльності, жодним чином не послаблює трансцендентну іншість цього посередника. Х. Анатоліос до Атанасієвого сутнісно-силового розрізнення наводить паралель із досить поширеним у його часі розрізненням між природою та іiі діяльністю. Оскільки Бог за своєю природою невидимий і недоступний, то Він являє себе через свої діла, в динаміці своєї творчої активності ${ }^{63}$. В обидвох випадках йдеться про антиномічне осмислення трансцендентності й іманентності Бога, про якого можна “одним подихом говорити”, що Він абсолютно віддалений у своїй іншості і водночас близький у своїй всюдисущності ${ }^{64}$. Участь у Божому Слові, Його силі, визначальна для людини, яка у своїй духовній дорозі прагне бути сопричасником Божого життя, богоспілкуватись, богопізнавати.

4. Божа сила й енергія в боголюдській синергії. Визначальний пункт в осмисленні Атанасієм Божої іманентності щодо світу - це особовий, боголюдський діалог. Мета цього діалогу, у якому Божі енергії співдіють з енергією людини, полягає в спасінні й обоженні людини. Для Атанасія Олександрійського проблема онтологічного взаємозв'язку між потусторонньою іншістю Божої природи і поцейбічністю сотвореного світу, як i поняттєво-концептуальна інтерпретація Божої всюдисущності у світі, грунтується передовсім на сотеріологічних передумовах. Це - визначальний богословський елемент для його антропології, онтології і космології, де олександрійський єпископ вибудовує “міст”, який перекриває дистанцію між божественною іншістю та близькістю щодо сотвореного світу. Оскільки Атанасій говорить сотеріологічною мовою, то для нього визначальною площиною дискусії є богословська інтерпретація можливості боголюдських стосунків, мета яких - оновлення людини, богопізнання й Обоження. Антиномічну подвійність природи Божого Буття олександрійський єпископ означує в сотеріологічному ракурсі духовного пошуку шляху до Бога:

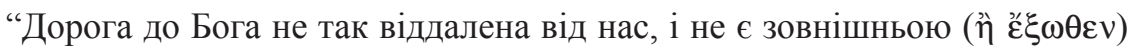
щодо нас, як сам Бог, який перебуває високо понад усім. Проте вона перебуває в нас, і ми самі здатні знайти їі початок"65.

\footnotetext{
і душа - це одна недоступна сфера, а Боже творіння і тіло - інша, пов'язана і водночас кардинально відмінна. A. Meredith, Emanation in Plotinus and Athanasius', StPatr 16 (1985) 317-323.

${ }^{62}$ Пop. Athanasius Alexandrinus, Oratio contra gentes 43, 1-3, ed. Thomson, c. 118.

${ }^{63}$ Пop. idem, Oratio de incarnatione Verbi 32, 2-6, ed. Thomson, c. 210-212; idem, Oratio contra gentes 35, 1-3. 5-9. 16-18, ed. Thomson, c. 94-96.

${ }^{64}$ Пop. Anatolios, Athanasius, c. 46.

${ }^{65}$ Athanasius Alexandrinus, Oratio contra gentes 30, 4-6, ed. Thomson, c. 82: “ov̉ $\delta$,
} 
Антиномічним твердженням щодо природи Бога, яка одночасно “не так віддалена" і “високо понад усім”, Атанасій ілюструє важливу істину: Божа трансцендентність - це не перепона для Його іманентності щодо людини, яка як творіння, живучи в сотвореній реальності, може знайти Божу дорогу, йти нею і пізнавати Того, хто “високо понад усім". К. Анатоліос, коментуючи цей текст, зазначає, що "Атанасій цим хоче сказати те, що відстань, якою Бог є «високо понад», не дорівнює відстані, якою Бог є «далекий». [...] Факт Божої трансцендентності не применшує можливості людського пізнання Бога"66.

3 огляду на наслідки гріхопадіння, духовно-аскетичний шлях християнина стає однією з головних тем у справі відновлення можливості Обоження людини ${ }^{67}$. У “Житті Антонія" Атанасій розглядає поняття Божої

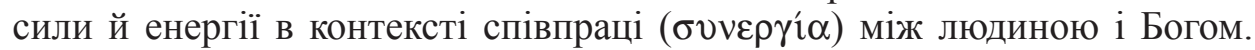

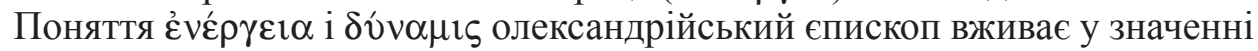

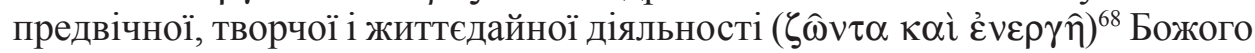
Слова у світі. Х. Анатоліос, коментуючи значення Божої сили та енергії у світобудові, зазначає, що іманентна активність творінь походить від предвічної діяльності Слова, яке

“своєю власною силою охоплює й урухомлює видимий світ і невидимі сили, надаючи кожному властиву їм діяльність” ${ }^{\circ}$.

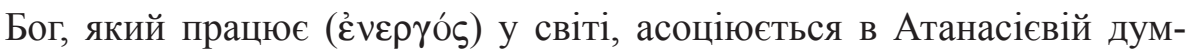

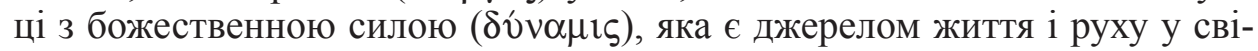

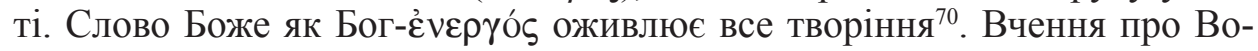
плочення в Атанасія безпосередньо пов'язане з інтерпретацією того,

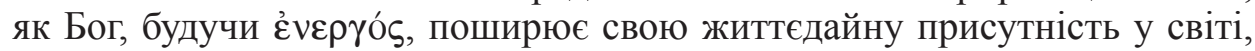
в людському тілі Христа й, особливо - у Христових учнях ${ }^{71}$. Слово Боже об'являє себе та Отця як правителя і керівника всього світу через тілесні

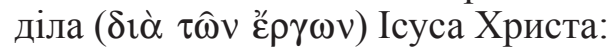

“Слово розповсюджується скрізь: зверху і знизу, вглиб і вшир; вгорі - творінні, внизу - у Воплоченні, вглиб - в аді, вшир - у світі. Все наповнене пізнанням Бога (пор. Ic. 11, 9). [...] Бо Спаситель двома шляхами

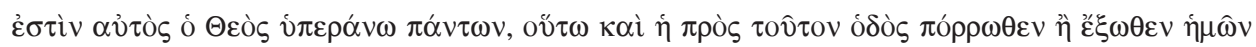

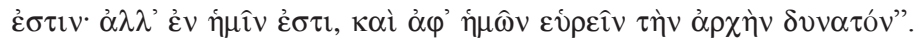

${ }^{66}$ Anatolios, Athanasius, c. 33-34.

${ }^{67}$ Про зв'язок сотеріологічно-христологічної думки Атанасія з його розумінням природи, мети і завдань духовного життя й аскетичного подвигу християнина див. Brakke, Athanasius and Asceticism, c. 356.

${ }^{68}$ Пop. Athanasius Alexandrinus, Oratio contra gentes 40, 29, ed. Thomson, c. 110.

${ }^{69}$ Ibidem 44, 25-28, ed. Thomson, c. 122. Пop. Anatolios, Athanasius, c. 177.

${ }^{70}$ Пор. Athanasius Alexandrinus, Oratio de incarnatione Verbi 1, 5-7. 24-35, ed. Thomson, c. $134-136$.

${ }^{71}$ Пop. Anatolios, Athanasius, c. 177-178. 
явив своє чоловіколюбіє через Воплочення: тим, що знищив у нас смерть й оновив нас, i тим, що залишаючись непізнаваним і невидимим, явив

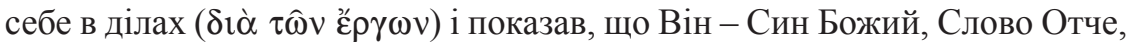
Провідник і Цар Всесвіту"72.

Апостольська діяльність Христових учнів - це своєрідна земна проекція предвічної діяльності Сина Божого. Така діяльність апостолів виходить із певності в силі й енергії Воскреслого Слова Божого. Атанасій

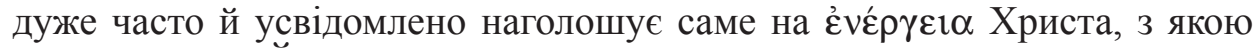
співпрацюють Його послідовники і яка служить джерелом та основою їх діяльності $^{73}$. На прикладі духовної боротьби св. Антонія Великого Атанасій показує, що саме Христовою силою й енергією подвижник у своєму духовному житті перемагає силу диявола ${ }^{74}$. Наголос на постійній дієвості Христа Воскреслого, живого і життєдайного бачимо в 30 главі праці Oratio de incarnatione Verbi. Наголошуючи на істинності Воскресіння Христового тіла, автор вказує те, що благочинність Христа розповсюджується скрізь і всюди як в утвердженні та сповіддані людьми своєї віри, так і в їхній синергії з Богом на духовно-аскетичному шляху боротьби i вдосконалення ${ }^{75}$. Своєрідним принципом богословської думки Атанасія стає те, що християнська діяльність у сходженні до святості походить із первинної діяльності та перемоги Христа над смертю. Будь-який страх, відчуття людської слабкості й немочі Христовий подвижник може перебороти радістю, що приходить від розуміння диявольського безсилля перед силою Христа ${ }^{76}$. Синергійна діалектика між людською та божественною діяльністю веде до логічного висновку: як би ми не осмислювали природу діяльності людини, завжди наші роздуми приведуть до певності в тому, що людська духовна динаміка основується і забезпечується силою та енергією Бога ${ }^{77}$. Атанасієвий образ Антонія Великого представляє модель, в якій людські чесноти і святість зрозумілі як такі, що походять

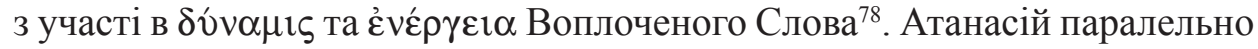

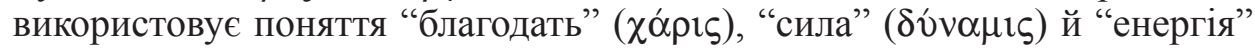

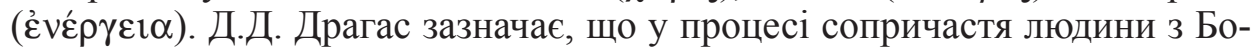
гом через Сина Божого відбувається передача сили ( $\mu \varepsilon \tau \alpha ́ \delta o \sigma \imath \varsigma ~ \delta v v o ́ \alpha \varepsilon \omega \varsigma)$ від Божого Логосу людині. Відкривається екзистенційна антропологічна перспектива наслідків дії Божої благодаті, затемненої і майже втраченої

${ }^{72}$ Пop. Athanasius Alexandrinus, Oratio de incarnatione Verbi 16, 12-15. 21-25, ed. Thomson, c. 172.

${ }^{73}$ Пop. Anatolios, Athanasius, c. 179-180.

${ }^{74}$ Пop. Athanasius Alexandrinus, Oratio de incarnatione Verbi 48-54, ed. Thomson, c. 255-271.

${ }^{75}$ Пop. ibidem 30, ed. Thomson, c. 206-208.

${ }^{76}$ Пор. Anatolios, Athanasius, c. 181. Див. Athanasius Alexandrinus, Vita Antonii 42.

${ }^{77}$ Пop. Anatolios, Athanasius, c. 180.

${ }^{78}$ Пор. ibidem, с. 183. Див. Athanasius Alexandrinus, Vita Antonii 5. 
після гріхопадіння ${ }^{79}$. Саме завдяки Воплоченню Слова Божого знищуються всі перепони для відновлення людської природи, осягнення контролю над тілесними пристрастями, оскільки панує над пристрастями у своєму тілі Воплочене Слово. Людина одержує можливість брати участь у Божому тілі, а відтак - в Його безпристрасності переображувати свою природу, свою тілесність на образ людськості Слова Божого. У Воплоченому Слові відкривається діаметрально протилежна сторона істини про радикальну відмінність між Творцем і Божим творінням. Нетлінність та безпристрасність від Воплоченого Сина Божого переходить на тих людей, які беруть у Ньому участь: у Його людськості й божественності. Смерть та гріх знищуються, анулюється неможливість богоспілкування і для людини відкривається нова можливість єднання з Богом-Словом. Динамічний антропологічно-сотеріологічний “міст” у цьому єднанні Атанасій називає "спорідненістю за плоттю" ". Воплочене Слово Боже обожує свою людську природу своєю силою й енергією. Люди ж, одержуючи можливість участі в Божому тілі, обожуються. Отож, Слово, приймаючи тіло, силою та енергією руйнує непрохідний бар'єр між Творцем і творінням, який з'явився після гріхопадіння, і відкриває “ворота в небо”" .

5. Природа і благодать. Для правильної інтерпретації Атанасієвого підходу до проблеми онтологічного розрізнення у Божій природі того, що понад і поза досягненням, і того, що об'являється людині і світу, важливо згадати також про його розмежування понять "природа" i “бла-

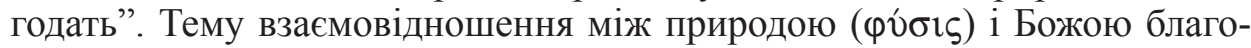

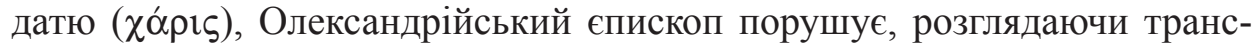

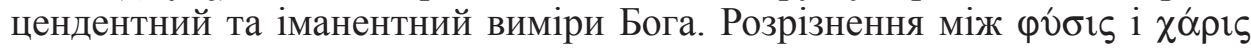
у богословленні Атанасія стосується фундаментального розрізнення між сотвореним та несотвореним буттям. Ці поняття дуже часто автор використовує в сотеріологічно-пневматологічному ракурсі, з одного боку, й антропологічно-аскетичному - 3 другого. Природа - це радикальна залежність від всюдисущого Творця, який іiі творить із нічого, формує і підтримує все творіння у бутті ${ }^{82}$. Динамічна всюдисущість Бога не означає, що Він стає єдиносущним із творінням. Боже Буття містить у собі і наповнює собою всі речі й істот, але "не обмежене ними”. “Залишаючись поза творінням своєю сутністю, Бог не припиняє своєї діяльності

${ }^{79}$ Пop. Dragas, The Relation of Nature to Grace in the Writings of St. Athanasius, c. 76.

${ }^{80}$ Атанасій, формулюючи значення Воплочення Сина Божого для знищення гріха, смерті і воз'єднання з Богом, наголошує, що оскільки діла диявола “зруйновані Його плоттю, то завдяки спорідненості за плоттю ми всі через це звільнились, і самі поєднались зі Словом. А поєднавшись із Богом, не залишимось вже на землі" (Athanasius Alexandrinus, Orationes contra Arianos II 69, PG 26, 293). Детальніше про це див. Brakke, Athanasius and Asceticism, c. 145-161; Kelly, Early Christian Doctrines, c. 378-379.

${ }^{81}$ Пop. Brakke, Athanasius and Asceticism, c. 149-151.

${ }^{82}$ Пop. Anatolios, Athanasius, c. 55. 
у ньому, а відтак творіння бере участь у Його власній діяльності" 83 . Так Атанасій зазначає:

“ІІнші речі відповідно до своєї первинної природи не подібні до сутності

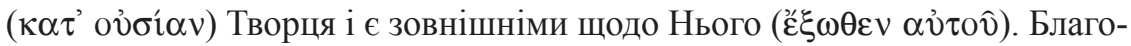

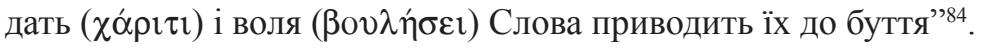

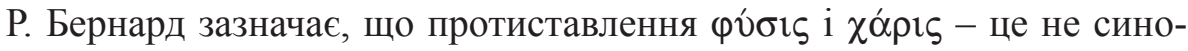
німічне вираження зв'язку між природним і надприродним, тут радше мовиться про трансцендентність несотвореного божества 3 одного боку

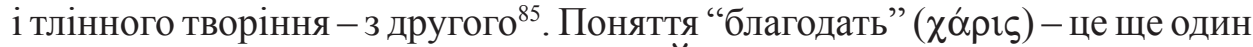
спосіб вираження Божого сходження і Його дієвої присутності у світі. Це поняття в олександрійського єпископа можна правильно розуміти, лише

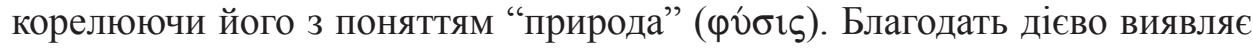
Божу турботу і дбайливість щодо сотвореного світу, оберігання всього

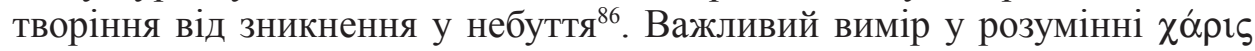
- відкриття можливості участі людини і всього творіння в Божому Бутті, яке за своєю сутністю залишається поза сотвореним, але завдяки своїй

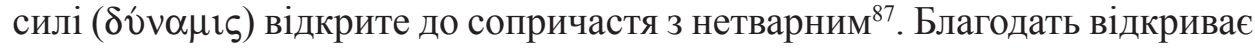
людині можливість самоусвідомлення, духовного переображення і споглядання Бога. Це вимагає від людини в синергії з благодаттю адекватного прийняття дії “божественної сили, через яку іï physis буде збережена і вдосконалена в існуванні" 88 .

Людина задіяна у своєрідній “природній” нестабільності цілої світобудови. Духовно-моральний стан людства і його занепад безпосередньо пов'язані зі всесвітньою дезінтеграцією. Головна ж драма людини - смерть, якої вона може уникнути лише за допомогою Божої благодаті, беручи участь в енергіях Божого Логосу. Саме благодать ${ }^{89}$ та енергії Слова Божого оберігають людську природу від руйнування, спотворення, занепаду та змін ${ }^{90}$. Благодать Христова животворить, вдосконалює

\footnotetext{
${ }^{83}$ Ibidem, c. 46 .
}

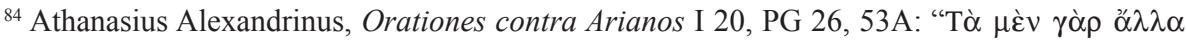

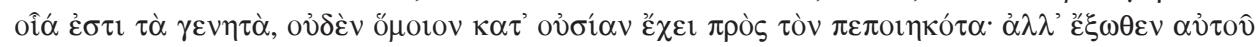

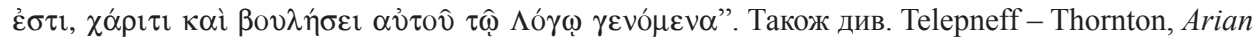
Transcendence and the Notion of Theosis, c. 274.

${ }^{85}$ Пop. R. Bernard, L'Image de Dieu d'apres saint Athanase, Paris 1952, 61.

${ }^{86}$ Пop. Athanasius Alexandrinus, Oratio contra gentes 41, ed. Thomson, c. 112-114.

${ }^{87}$ Пop. Anatolios, Athanasius, c. 56.

${ }^{88}$ Dragas, The Relation of Nature to Grace in the Writings of St. Athanasius, c. 77.

${ }^{89}$ Про природу і дію Божої благодаті в богослов'ї Атанасія Олександрійського див. M.F. Wahba, The Doctrine of Sanctification in St. Athanasius' Paschal Letters, Cairo - Rhode Island 1988, 123-127, 144-147, 158-162.

${ }^{90}$ Про це див. Athanasius Alexandrinus, Oratio contra gentes 40-43, ed. Thomson, c. 108-121; idem, Oratio de incarnatione Verbi 2, 3, 5, ed. Thomson, c. 136-147. 
і просвітлює людське життя ${ }^{91}$. Говорячи про пневматологічний вимір сотеріології, Атанасій виокремлює саме дію благодаті Святого Духа, яку одержують Христові апостоли в час П'ятдесятниці. Христос дає цю благодать Духа тим, хто Його просить. Тут поняття “благодать” виступає своєрідним уточненням того, “чим” постійно діє Дух Божий, освячуючи людину ${ }^{92}$. Атанасій порівнює Божу благодать із насінням, яке Христос насаджує в людські серця і яке приносить свої плоди очищення й освячення ${ }^{93}$. Перед Воплоченням благодать діяла на праведників ніби ззовні, натомість із Христовим приходом людина одержала можливість наповнюватись нею вщерть ${ }^{94}$. Саме завдяки благодаті душі вірних приймають "Господню силу", яка їх обожує. Вони беруть участь у Бозі й стають синами Божими саме за Його благодаттю ${ }^{95}$.

$$
* * *
$$

Підсумовуючи, зазначимо, що Атанасій Олександрійський зі своєю індивідуальною специфікою, головно спричиненою сотеріологічнохристологічною полемікою його часу, поглиблює розуміння й інтерпретацію проблеми онтологічної віддаленості та близькості між Творцем i творінням, Богом і людиною. 3 одного боку, він використовує вже звичну апофатичну лексику для окреслення буттєвої іншості Бога, з іншого - не творить відокремленого від світу, безликого, “філософського” Бога. Атанасій розгортає образ люблячого божественного Отця, який входить у світ своєю дієвою добротою, турботою і чоловіколюбієм.

Трансцендентний у собі, Бог діяльно насичує всесвіт своєю люблячою і щедрою присутністю завдяки впорядковуючій все творіння божественній силі, енергії, благодаті. Він, залишаючись трансцендентним, іманентно та незбагненно близько, проникає у всі виміри сотвореної

\footnotetext{
${ }^{91}$ Про освячувальну дію благодаті Сина Божого у христології Атанасія див. Ј.В. Berchem, Le Christ Sanctificateur d'apres Saint Athanase, “Angelicum” (1938) 515-558.

${ }^{92}$ Пор. Wahba, The Doctrine of Sanctification in St. Athanasius' Paschal Letters, c. 93-95.

${ }_{93}^{93}$ Пор. ibidem, с. 124-126, 145-146. Подібно до притчі про сіяча, пор. Мт. 13, 1-23.

${ }^{94}$ Пор. Berchem, Le Christ Sanctificateur d'apres Saint Athanase, c. 557.

${ }^{95}$ Пор. Athanasius Alexandrinus, Orationes contra Arianos III 25, PG 26, 376: “Ми - сини і боги завдяки Слову, яке в нас перебуває, [...] в нас той самий Дух, який і в Слові, сущому в Отці”. В іншому місці цього ж твору Атанасій зазначає: “Один $є$ Син за природою, істинний і єдинородний, але й ми стаємо синами, подібними до Нього, не за природою і не в дійсності, а за благодаттю Того, хто покликав, i, залишаючись земними людьми, називаємось богами, не такими, яким є Бог і яким $є$ істинне Його Слово, але як захотів Бог, який це дарує. [...] Він за природою і сутністю - Слово й істинний Бог [...], а ми за усиновленням і благодаттю через Нього стаємо синами, причащаючись Його Духа. [...] Ми за наслідуванням стаємо доброчинними й синами" (ibidem III 19, PG 26, 361C - 364A-B). Атанасій, розглядаючи христологічний вимір Обоження людини, не забуває наголосити і на пневматологічному вимірі обожуючої дії. Пор. idem, Epistula ad Serapionem 1, 23-25, ed. J. Lebon, SCh 15, Paris 1947, 124-129.
} 
природи своєю добротою. Онтологія, космологія й етика в богослов”і Атанасія творять своєрідний рівносторонній трикутник. Дія, енергія, сила, благодать Божа виходять 3 “віддаленості" Божої несотвореної природи та наповнюють благодатною “близькістю” життєдайної любові сотворену природу світу. Джерелом і посередником сходження й присутності у всесвіті Отцівської енергії любові є Божественний Логос, який, залишаючись трансцендентним, працює у світі, наповнює сотворене буття іманентністю Божого дієвого піклування, яке внутрішньо формує і облаштовує увесь космос і людину. Атанасій розрізняє як христологічний вимір сходження Слова Божого у світ, так і енергійний його вимір, показуючи іпостасну, енергійно-силову та космологічну сторони Отцівської ікономії, Воплочення Слова та динаміки людського богопізнання. Бог себе об'являє і дає пізнати також через свої імена, які також іманентно уприсутнюють його трансцендентну природу. Вже не існує радикального онтологічного відокремлення сотвореної і несотвореної природи із Воплоченням й енергійною всюдиприсутністю Божої турботи і підтримки. Світ і людина стають причасниками життєдайної та творчої енергії Воплоченого Слова, який своєю премудрістю звершує і сакраменталізує гармонійну світобудову. Центром взаємодії несотвореного і сотвореного в Атанасієвій думці є боголюдські стосунки, які оновлюють людину і ведують іï до богопізнання й Обоження.

\section{CREATOR AND CREATION, GOD AND THE HUMAN PERSON, ESSENCE AND ENERGY IN THE THEOLOGY OF ATHANASIUS OF ALEXANDRIA}

\section{(Summary)}

The article discusses the problem of the ontological distinction between God's transcendence and immanence in the theological thought of Athanasius of Alexandria, a Church Father of the IV century. The author presents the main conceptual and terminological apparatus that Athanasius used in his antinomic approach to the "reconciliation" of apophatic and kataphatic images of God. He analyzes the key characteristics of these two dimensions of the nature of God. Special attention is paid to the analysis of the kataphatic approache in answering the question: how can God, who is completely ontologicaly removed from created reality, be at the same time actively present in the world and filling it. In this context the author analyzes the key notions, which express the "intradivine" remoteness and God's active nearness in relation to created being. 
STWÓRCA I STWORZENIE, BÓG I CZŁOWIEK, ISTOTA I ENERGIA
W MYŚLI TEOLOGICZNEJ ATANAZEGO ALEKSANDRYJSKIEGO

(Streszczenie)

Artykuł omawia problem rozróżnienia ontologicznego między Boską transcendencją oraz immanencją w myśli teologicznej Atanazego Aleksandryjskiego, Ojca Kościoła IV wieku. Autor przedstawia podstawowy aparat pojęciowy oraz terminologiczny stosowany przez Atanazego w jego antynomicznym podejściu do „pogodzenia” między apofatycznym i katafatycznym obrazem Boga. Analizuje on właściwości kluczowe tych dwóch wymiarów natury Boga. Szczególna uwaga została poświęcona analizie katafatycznego podejścia do odpowiedzi na pytanie: w jaki sposób Bóg, całkowicie oddalony w aspekcie ontologicznym od rzeczywistości stworzonej, może jednocześnie być aktywnie obecny w świecie i napełniać go? W tym kontekście autor analizuje pojęcia kluczowe, które wyrażają „,wewnątrzboskie” oddalenie oraz aktywną bliskość Boga w odniesieniu do bytu stworzonego.

Key words: Athanasius, apophatic, kataphatic, essence, condescension, divine energy, divine power, nature, grace.

Slowa kluczowe: Atanazy, apofatyka, katafatyka, istota, łaskawość, Boska energia, Boska siła, Boska natura, łaska.

Ключові слова: Атанасій, апофатика, катафатика, сутність, Божі сходження, Божа енергія, Божа сила, Божа природа, благодать.

\section{БІБЛІОГРАФІЯ}

\section{Джерела}

Athanasius Alexandrinus, Epistula ad Epictetum, PG 26, 1049-1069.

Athanasius Alexandrinus, Oratio contra gentes, ed. R.W. Thomson, B: Athanasius,

Contra Gentes and De Incarnatione, Oxford Early Christian Texts, Oxford 1971,

2-133.

Athanasius Alexandrinus, De decretis Nicaenae synodi, PG 25, 416-476.

Athanasius AleXandrinus, Oratio de incarnatione Verbi, ed. R.W. Thomson, B: Athanasius,

Contra Gentes and De Incarnatione, Oxford Early Christian Texts, Oxford 1971, 134-276.

Athanasius Alexandrinus, Sermo ad Antiochum ducem, PG 28, 589-597.

Athanasius Alexandrinus, Epistulae ad Serapionem, ed. J. Lebon, SCh 15, Paris 1947.

Athanasius Alexandrinus, Orationes contra Arianos, PG 26, 12-468.

Athanasius Alexandrinus, Vita Antonii, PG 26, 837-976.

Наукові праці

Anatolios K., Athanasius: The coherence of his thought, London - New York 1998.

Berchem J.B., Le Christ Sanctificateur d'apres Saint Athanase, "Angelicum" (1938) $515-558$. 
Bernard R., L'Image de Dieu d'apres saint Athanase, Paris 1952.

Brakke D., Athanasius and Asceticism, Baltimore - London 1995.

Dragas G.D., The Relation of Nature to Grace in the Writings of St. Athanasius, B: Saint Athanasius of Alexandria. Original Research and New Perspectives, Rollinsford 2005.

Florovsky G., The Concept of Creation in St. Athanasius, StPatr 6 (1962) 36-57.

Флоровский Г.В., Восточные Отиы IV-го века, Москва 1992.

HARnACK A., Lehrbuch der Dogmengeschichte, vol. 2, Freiburg - Leipzig 1894.

Kelly J.N.D., Early Christian Doctrine, London 1968.

Louth A., Athanasius's Understanding of the Humanity of Christ, StPatr 16 (1985) 309-318.

Meredith A., Emanation in Plotinus and Athanasius, StPatr 16 (1985) 317-323.

Morales X., La théologie trinitaire d'Athanase d'Alexandrie, Collection des Études Augustiniennes, Série Antiquité 180, Paris 2006.

Pettersen A., A Good Being Would Envy None Life: Athanasius on the Goodness of God, “Theology Today" 55 (1998) 59-68.

Pettersen A., Athanasius and the Human Body, Bristol 1990.

Pettersen A., Athanasius, London 1995.

Telepneff G. - Thornton J., Arian Transcendence and the Notion of Theosis in Saint Athanasios, GOTR 32 (1987) 271-277.

Wahba M. F., The Doctrine of Sanctification in St. Athanasius' Paschal Letters, Cairo - Rhode Island 1988.

WARE K., God Hidden and Revealed: The Apophatic Way and the Essence-Energies Distinction, "Eastern Church Review" 7 (1975) 125-136.

Weinandy T., Athanasius. A Theological Introduction, Hampshire - Burlington 2007.

Williams A.R., Arius: Heresy and Traditio, London - Darton 1987. 
